The Journal of Animal \& Plant Sciences, 30(6): 2020, Page: 1612-1621

ISSN (print): 1018-7081; ISSN (online): 2309-8694

\title{
ROLE OF COMPATIBLE POLLINIZER FOR COMMERCIAL OLIVE PRODUCTION IN POTHWAR, PAKISTAN.
}

\author{
M. A. Iqbal' ${ }^{1}$ A. Mahmood ${ }^{2}$, M. A. Khan ${ }^{3}$, T. Ahmad ${ }^{3}$, M. Azam 4 , M. I. N. Bhatti ${ }^{5}$, A. A. Awan ${ }^{6}$ and I. A. Hafiz ${ }^{3 *}$ \\ ${ }^{1}$ Barani Agricultural Research Institute, Chakwal, ${ }^{2}$ Ayub Agriculture Research Institute, Faisalabad, ${ }^{3}$ Department of \\ Horticulture, PMAS-Arid Agriculture University, Rawalpindi Pakistan, ${ }^{4}$ Institute of Horticultural sciences, University of \\ Agriculture, Faisalabad, ${ }^{5}$ Izhar Olive Farm, Kalar Kahar, ${ }^{6}$ Pakistan, Pakistan Oilseed Development Board \\ ${ }^{*}$ Correspondence: decenthafiz@gmail.com
}

\begin{abstract}
The final fruit yield is significantly correlated to fruit set which is directly dependent upon self-incompatibility (SI), pollination ability, extent of cross-compatibility among cultivars, and prevailing environmental conditions especially suitable temperature regimes during anthesis. Four Italian cultivars viz. Coratina, Frantoio, Ottobratica, and Leccino under the agro-climatic conditions of Pothwar (Pakistan) were included in these studies during the years of 2017 \& 2018. Each variety exhibited different values for the initial fruit set, final fruit set, number of shotberries and extent of selfincompatibility index. The SI resulted through reciprocal crosses depicted that cv. Coratina (0.80), cv. Frantoio $(0.67)$ and cv. Leccino (0.73) possessed partial self-incompatibility while cv. Ottobratica (0.43) was found completely selfincompatible in studied environmental conditions. Cross-compatibility results based on fruit set percentage indicated that the cultivars can efficiently pollinize other cultivars and set good fruit yield, however, the cultivars pairs Coratina/Frantoio was at top and pair of Ottobratica/ Leccino was at the bottom. Thus, the selection and plantation of suitable pollinizers in olive orchards is a prerequisite through which deficiency in fruit setting and attaining commercial yield in olive orchards could be achieved.
\end{abstract}

Keywords: olive, Pakistan, self-incompatibility index, pollinizer, cross-compatibility.

https://doi.org/10.36899/JAPS.2020.6.0182

Published online August 03,2020

\section{INTRODUCTION}

Olive is the most important oil producing tree of the Mediterranean region included Turkey, Syria, Palestine, and Israel but the origin of cultivated olive remained unclear (Concepcion et al., 2014). Spain is the largest olive producer with a production of more than 900000 tons of olives per annum. From overall world production, Italy and Spain together account for 50\%. In the world, 2713.5 thousand tons of olive oil is being produced on a commercial scale in 47 countries of 5 continents (Mansour et al., 2018).

Olive (Olea europaea L.) is an evergreen fruit tree and its oil has a beneficial effect on human health due to its special nutritional values (Estruch et al., 2013). Pakistan is the fourth largest edible oil importing country in the world which imports $70 \%$ of the total edible oil by spending a lot of money (2.710 billion US\$) in lieu of import bill that is increasing at an alarming rate (Kiran, 2017). Presently, the increase in per capita consumption of edible oil has jumped from 17 to $18 \mathrm{Kg}$ during the last five years (Rashid, 2018). Olive cultivation and its consumption have extended other than Mediterranean belts such as Pakistan, China, India, Australia, and the Southern part of America during the last 20 to 30 years (Awan et al., 2011). Although Pakistan has a short history of olive cultivation, yet during the last ten years olive plantation has gained popularity because of its great socio-economic importance. More than 4494.36 hectares area has been brought under olive plantation in the Pothwar region while more than 2,800 acres $(280,004$ plants) in other parts of the country including Southern KP and Baluchistan (PARC, 2018; BARI, 2019).

The optimum temperature range for the development of the reproductive bud is $2{ }^{\circ} \mathrm{C}$ to $19{ }^{\circ} \mathrm{C}$ (Malik and Perez, 2011, Torres et al., 2017). However, the temperature higher than $30{ }^{\circ} \mathrm{C}$ severely inhibits the pollination process irrespective of the cultivars; thus results in increase self-incompatibility or lower the efficiency of the cross or open pollination. Harsh environmental conditions at blooming, anthesis, fertilization, or just after the fertilization critically influence the pollination and fruit yield (Koubouris et al., 2009; Rapoport, 2012; Rondanini et al., 2014). Selfincompatibility is the characteristics which are associated with many olive genotypes which also depends upon environmental conditions, high temperature, nutrients profile of soil, water availability, pollination ability, percentage of pollinator varieties and failure of pollen tube emergence from pollens, slow or delay the growth of pollen tube in the style (Saumitou-Laprade et al., 2017; Torres et al., 2017).

Pakistan has not true to type Mediterranean climatic conditions however, a limited number of olive 
varieties were cultivated in different parts of Pothwar, Khyber Pakhtunkhwa and Balochistan. The data was collected upon only yield and oil content. Fruit yield per tree was significantly affected by cultivars, locations, and various physiological and reproductive processes such as flower differentiation, floral induction and fruit set (Iqbal et al., 2019a, Webster, 2002). The yield was found very poor (10 to $12 \mathrm{~kg} /$ Tree) in prominent varieties like Coratina, Leccino, and Pendolino (Awan and Rab, 2014).

Thus, before the establishment of the olive industry in Pakistan, the performance of exotic cultivars requires investigations regarding its self-incompatibility, pollinizing efficiency, high-temperature sensitivity and cross-compatibility. Based on these facts, the present study was designed to record the role of pollinator varieties, degree of self-incompatibility of prominent cultivars under the agro-climatic conditions of the Pothwar region, and to determine the best pollinizer among these cultivars to get maximum fruit set.

\section{MATERIALS AND METHODS}

Experimental site and plant material: The experiment was carried out in two consecutive years i.e. 2017 and 2018 at 7-8 years old well established commercial olive orchard "Izhar Olive Farm" located at Kallar Kahar, Chakwal, Northern Punjab, Pakistan (320 46'33 N and $7204231 \mathrm{E}$ ) at $460 \mathrm{~m}$ above the sea level. The metrological data was recorded through the local weather station (Sensovant, Spain) installed at the site. The detail of the metrological data during the observation period and soil profile analysis were presented in Fig. 1 and Table 1 respectively.

Four olive cultivars including Frantoio, Coratina, Leccino, and Ottobratica were selected. These cultivars constitute the major portion of the orchards planted in the Pothwar region of Pakistan. For the experiment, twelve trees of each cultivar of the same age, height, and growth vigor were selected. All the trees were of seven to eight years old with uniform canopy planted at a distance of $6 \mathrm{~m} \times 6 \mathrm{~m}$. The trees were pruned to a central open shape. The orchard management practices (irrigation, fertilization, hoeing, weeding, were the same for all the cultivars. Trees were irrigated through high efficient drip irrigation system ten times per year.

Experimental Layout: Three different treatments were applied i.e Self-pollination, Controlled cross-pollination and Open pollination. The experiment was laid out according to randomized complete block design (RCBD) with three replications In the process of self-pollination, 20 healthy floral shoots, uniform in length and distribution were bagged with pollination papers randomly on all four sides (east, west, north, south) of canopy at white flower stage, a few days before opening the flowers. Hence, there was no chance of receipt of foreign pollen and surety of self-pollination at full bloom by falling of self-pollen on stigma. Then at the petal fall stage or when browning of petal occurred data were collected (Selak et al., 2011). To check the crosscompatibility, 20 other flowering shoots were randomly marked on the same plant and were left for free windpollination. Then at the petal fall stage or when browning of petal occurred, the data was collected for initial fruit set $\%$, number of shotberries per branch, final fruit set $\%$, and self-incompatibility index (Cuevas and Polito, 2004; Selak et al., 2011).

To check the control cross-compatibility, 30 uniform flowering shoots were randomly marked on the each plant of a cultivar, and isolated by paper bags. Out of them, 10 branches were bagged for pollen collection and 20 for cross-pollination. Flowers in the bags were not emasculated for reflection of existing field conditions. Cross-pollination treatments were performed during the period of full bloom. The floral shoots of pollen donor cultivars with nearly opened flowers were separated from the mother plant. Cross-pollination treatments were done with opening the bags under optimal weather conditions (no wind and rain), placing the branches of donor pollinator, and finally enclosing them in the bags. The bags with both types of floral shoot (mother and donor) were shaken on a daily basis for better pollination. The selected shoots were enclosed until the end of the petal fall (end of stigma receptivity) according to the method of Selak et al., (2011). Normally, it takes 2-3 days in an individual inflorescence, 5-6 days in an individual tree, but 10-15 days in cooler environments (Fabbri et al., 2004). When the temperature is unstable, anthesis may occur in more than one flush, but the first flush usually sets the fruit that reach maturity (Lavee et al., 1985). Each variety was used as a pollen donor for each and every other three varieties (Fig.2).

Data regarding initial fruit set $(\%)$ was recorded at petal fall stage one month after anthesis $\left(1^{\text {st }}\right.$ week of May), final fruit set (\%) was calculated after one month of initial fruit set ( $1^{\text {st }}$ week of June) and the number of shotberries were recorded. The index of selfincompatibility was calculated by using the following formula according to the previous studies (Cuevas and Polito, 2004). The categories of self-incompatibility have been shown in Table 2 .

ISI $=($ Final fruit set under self-pollination/fruit set under free pollination

The collected data were analyzed through statistically software 8.1. The two-way ANOVA analysis was carried out and least significant difference (LSD) was utilized to compare the means at $p \leq 0.05$ (Anonymous, 2005) 


\section{RESULTS}

Initial Fruit Set (\%): The mean maximum initial fruit set was recorded in variety Leccino $(13.75 \%)$ followed by Frantoio $(9.71 \%)$ and Coratina $(8.50 \%)$. While the variety Ottobratica $(7.68 \%)$ showed minimum initial fruit set \% (Table 3). As for the comparison of self and cross-pollination is concerned, cross-pollination showed a higher initial fruit set $(10.62 \%)$ as compared to selfpollination $(9.21 \%)$. The interaction between $\mathrm{V} \times \mathrm{T}$ depicted that the maximum initial fruit set was observed in a variety of Leccino in cross-pollination (13.91\%) followed by self-pollination $(13.59 \%)$. The variety Frantoio found at $2^{\text {nd }}$ position with maximum initial fruit set in cross-pollination (10.47 \%). While, variety Ottobratica was found at the lowest level $(6.8 \%)$ with a nearby variety Coratina $(7.48 \%)$ in self- pollination. The interaction between $\mathrm{V} \times \mathrm{Y}$, it was concluded that variety Leccino was found at the top with the values of maximum initial fruit set $(13.86 \%)$ and $(13.64 \%)$ in $1^{\text {st }}$ and $2^{\text {nd }}$ year of self and cross-pollination process respectively. Variety Frantoio was ranked at $2^{\text {nd }}$ position, Coratina at $3^{\text {rd }}$, and variety Ottobratica was found at the bottom level (Table 3 ). The interaction among $\mathrm{V} \times \mathrm{T} \times \mathrm{Y}$, the maximum values for initial fruit set were recorded for variety Leccino in both the years in self and crosspollination while Ottobratica remained at the lowest level in both the years and in treatments. In this case varieties, Coratina and Frantoio were found at a satisfactory level (Table 3).

The results of controlled cross-pollination depicted that the maximum initial fruit set was obtained in variety Leccino $(13.99 \% \& 13.20 \%)$ in both the years in case of self-pollination closely followed by the cross of Leccino and Frantoio and cross of Leccino and Coratina (Fig.3). All the crosses of varieties Coratina and Frantoio showed satisfactory results. Poor performance was obtained in the crosses of variety Ottobratica. In the case of variety Coratina as a female best cross was found with variety Frantoio in both the years with the values of 9.25 $\%$ and $9.49 \%$ in 2017 and 2018 respectively (Fig. 3). In the case of variety Frantoio used as female, maximum initial fruit set was obtained when it was crossed with Ottobratica $(9.47 \%)$ in 2018 and cross with variety Coratina $(8.76 \%)$ in 2017 . As well as the Ottobratica used as a female was concerned, the maximum initial fruit set $(9.98 \%)$ was obtained in 2018 when it was crossed with a variety of Frantoio. However, variety Leccino depicted the maximum initial fruit set in selfpollination treatment. Overall, the initial fruit set \% was found satisfactory in all crosses except in Ottobratica during self-pollination treatment (Fig. 3).

Final Fruit Set (\%):In the process of self and crosspollination, the final fruit set percentage was significantly $(\mathrm{P} \leq 0.05)$ affected by varieties and treatments. The results of Table 4 depicted that the maximum final fruit set was obtained in a variety of Coratina (3.35\%) closely followed by Frantoio $(3.21 \%)$. The variety Leccino ranked at $3^{\text {rd }}$ position $(1.46 \%)$ while variety Ottobratica ranked at bottom level $(1.07 \%)$. The interaction between $\mathrm{V} \times \mathrm{T}$ depicted that variety Frantoio showed maximum fruit set in cross-pollination $(3.99 \%)$ followed by a variety of Coratina $(3.78 \%)$. The Ottobratica showed a minimum value in self $(0.20 \%)$ but showed satisfactory results in cross-pollination (1.94\%). In comparison of $\mathrm{V} \times \mathrm{Y}$, it was depicted that all the varieties performed best in $2^{\text {nd }}$ year except variety Coratina which showed less fruit set as compared to 2017 (Table 4). In comparison of $\mathrm{V} \times \mathrm{T} \times \mathrm{Y}$, variety Frantoio showed maximum value (4.37 $\%$ ) in cross-pollination in $2^{\text {nd }}$ year of production. Overall variety Ottobratica was found at the bottom level in selfpollination in both the year with maximum value in $2^{\text {nd }}$ year $(0.25 \%)$ than $1^{\text {st }}$ year $(0.16 \%)$.

In the process of controlled cross-pollination, the results showed that the maximum final fruit set was obtained in a variety of Coratina when it was crossed with the pollens of variety Frantoio (3.68 \%) in 2018 (Fig.4). For the variety Frantoio used as a female, the data depicted the maximum final fruit set was obtained in variety Frantoio, when it was crossed with the pollens of variety Ottobratica (3.24\%) and Coratina (2.98\%). The results for controlled cross-pollination in variety Ottobratica portrayed the maximum final fruit set when it was made a cross with the pollens of variety Frantoio and Coratina in both the years (Fig. 4).

In the case of variety Leccino used as a female, the data described maximum final fruit set obtained when it was crossed with the pollens of variety Coratina $(2.59$ \%) in 2017 and with Frantoio in 2018 (2.45\%). In the overall scenario of final fruit set $\%$, the variety Ottobratica and Leccino performed poor in case of selfcompatibility while varieties Coratina and Frantoio performed well and found self-compatible. From the glance of Fig. 4, it was also concluded that varieties of Ottobratica and Leccino can play a better role as a pollinator but results for varieties Frantoio and Coratina as a pollinator were found at the top for all the cases.

Number of Shotberries per Branch: The maximum number of shotberries per branch was recorded in variety Leccino (22.11) followed by Ottobratica (21.67). Varieties Coratina and Frantoio showed less number of shotberries (Table 5). Maximum numbers of shotberries were found in self-pollination (19.47) as compared to cross-pollination (18.69) with statistically non-significant results. Higher numbers of shotberries were recorded in $2^{\text {nd }}$ year (19.48) as compared to 1 st year $(18.61 \%)$. The data regarding the interaction between $\mathrm{V} \times \mathrm{T}$ depicted that, variety Ottobratica showed the maximum number of shotberries in self-pollination (22.65) followed by Leccino in cross-pollination (22.35). In comparison in 
between $\mathrm{V} \times \mathrm{Y}$, the data depicted that more number of shotberries were found in Leccino (22.9) in $2^{\text {nd }}$ year followed by Ottobratica $(21.70)$ in $1^{\text {st }}$ year. While varieties Frantoio and Coratina showed satisfactory results by producing less number of shotberries (Table 5). In comparison of $\mathrm{V} \times \mathrm{T} \times \mathrm{Y}$, it was concluded that variety Ottobratica presented the maximum number of shotberries in self-pollination (23.61) at $2^{\text {nd }}$ year of production followed by variety Leccino (22.71) in crosspollination in the same year. The first seven values in this interaction were related to varieties of Leccino and Ottobratica in all treatments and years. The last two positions were occupied by varieties Coratina in selfpollination at $1^{\text {st }}$ year $(14.43)$ and Frantoio in crosspollination at $2^{\text {nd }}$ year $(13.15)$. Varieties Frantoio and Coratina could be selected for cultivation in study areas on the basis of minimum numbers of shotberries and maximum final fruit set percentage.

In the process of controlled cross-pollination (Fig. 5), a maximum of three values of the number of shotberries viz 25.43, 25.37, and 24.83 were found where variety Leccino was involved either as a pollinator or as a female. In the second higher-level number of shotberries were found during the process of self-pollination especially in varieties Ottobratica and Leccino. Varieties Frantoio and Leccino showed a satisfactory level by producing less number of shotberries in the selfpollination process. In all the crosses variety Frantoio proved itself a good pollinator for all types of crosses on the basis of less number of shotberries (Fig. 5).
Self-Incompatibility Index: For all the olive cultivars understudy, self-incompatibility index was calculated to estimate the level of self-sterility in each cultivar grown under the agro-climatic conditions of the Pothwar region. The significant variation was noted between years and varieties. Interactions between olive varieties and year $(\mathrm{V} \times \mathrm{Y})$ also were found significant against the selfincompatibility index. The results depicted the maximum value was recorded in $1^{\text {st }}$ year $(0.82)$ as compared to $2^{\text {nd }}$ year (0.49) (Table 6). In comparison of varieties, it was concluded that three varieties Coratina, Leccino and Frantoio showed less self-incompatibility as compared to Ottobratica. The Variety Coratina was found at the top with a value of 0.80 regarding the self-incompatibility index as compared to all other varieties. The interaction between $\mathrm{V} \times \mathrm{Y}$ depicted that variety Leccino showed maximum self-incompatibility index $(0.91)$ in $1^{\text {st }}$ year followed by a variety of Coratina (0.84) and Frantoio $(0.78)$ in the same year. The variety Ottobratica showed a minimum self-incompatibility index in $2^{\text {nd }}$ year $(0.10)$. Ottobratica was found less fruit set in the selfing process in both the years of study which clearly indicated that the variety of Ottobratica behaved as severely selfincompatible genotype. Overall, these results showed that all the studied olive cultivars possessed the phenomenon of self-incompatibility which was varied from cultivar to cultivar. Hence, all these cultivars need pollens from other olive cultivars to produce a high yield in terms of fruit production.

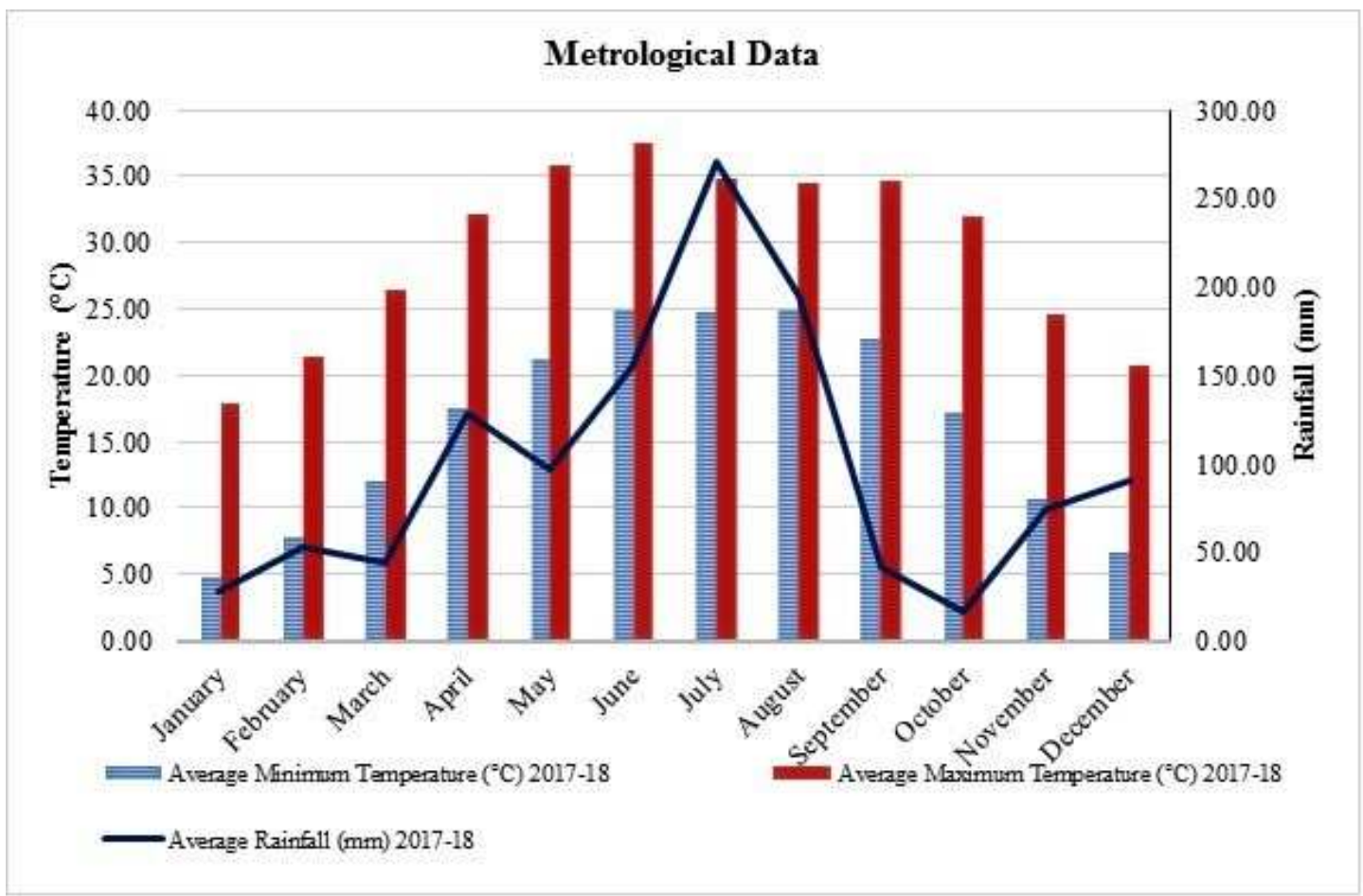

Figure 1. Average minimum temperature $\left({ }^{\circ} \mathrm{C}\right)$, maximum temperature $\left({ }^{\circ} \mathrm{C}\right)$ and rainfall $(\mathrm{mm}) 2017$ and 2018. 

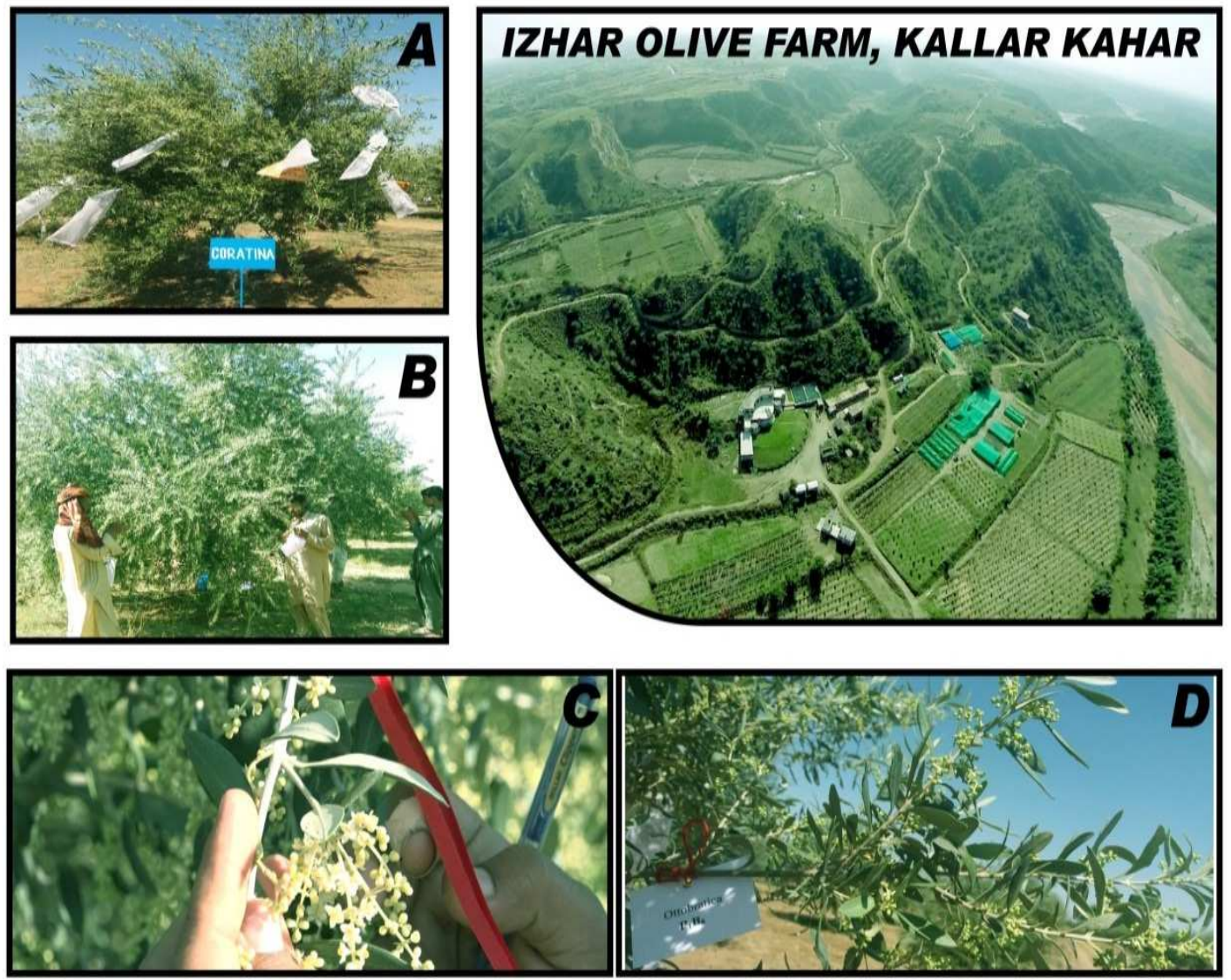

Figure 2. Self, cross and controlled cross treatments at Izhar Olive Farm, Kallar Kahar.

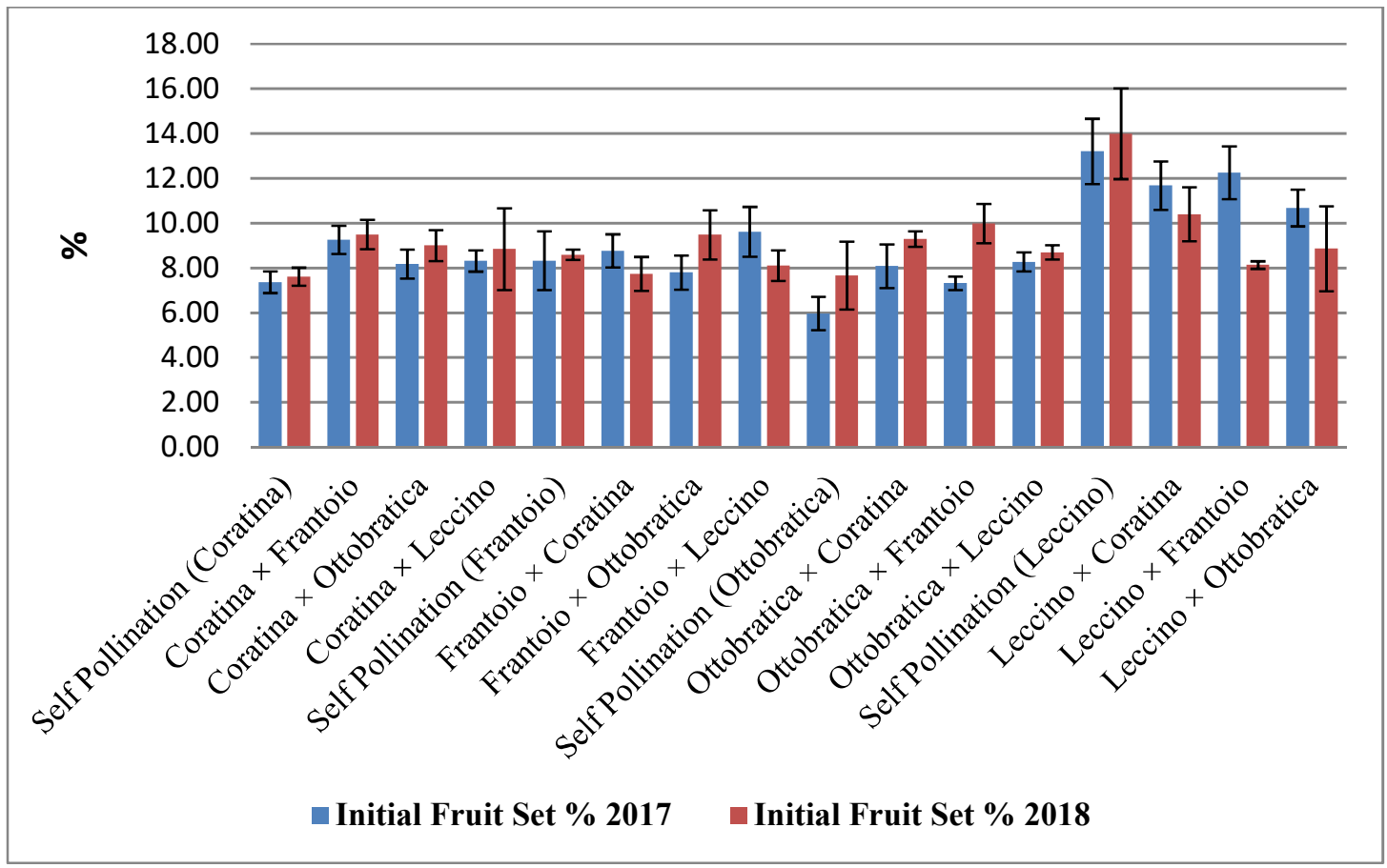

Figure 3. Initial fruit set (\%) of four olive varieties during crosses in diallel fashion. 


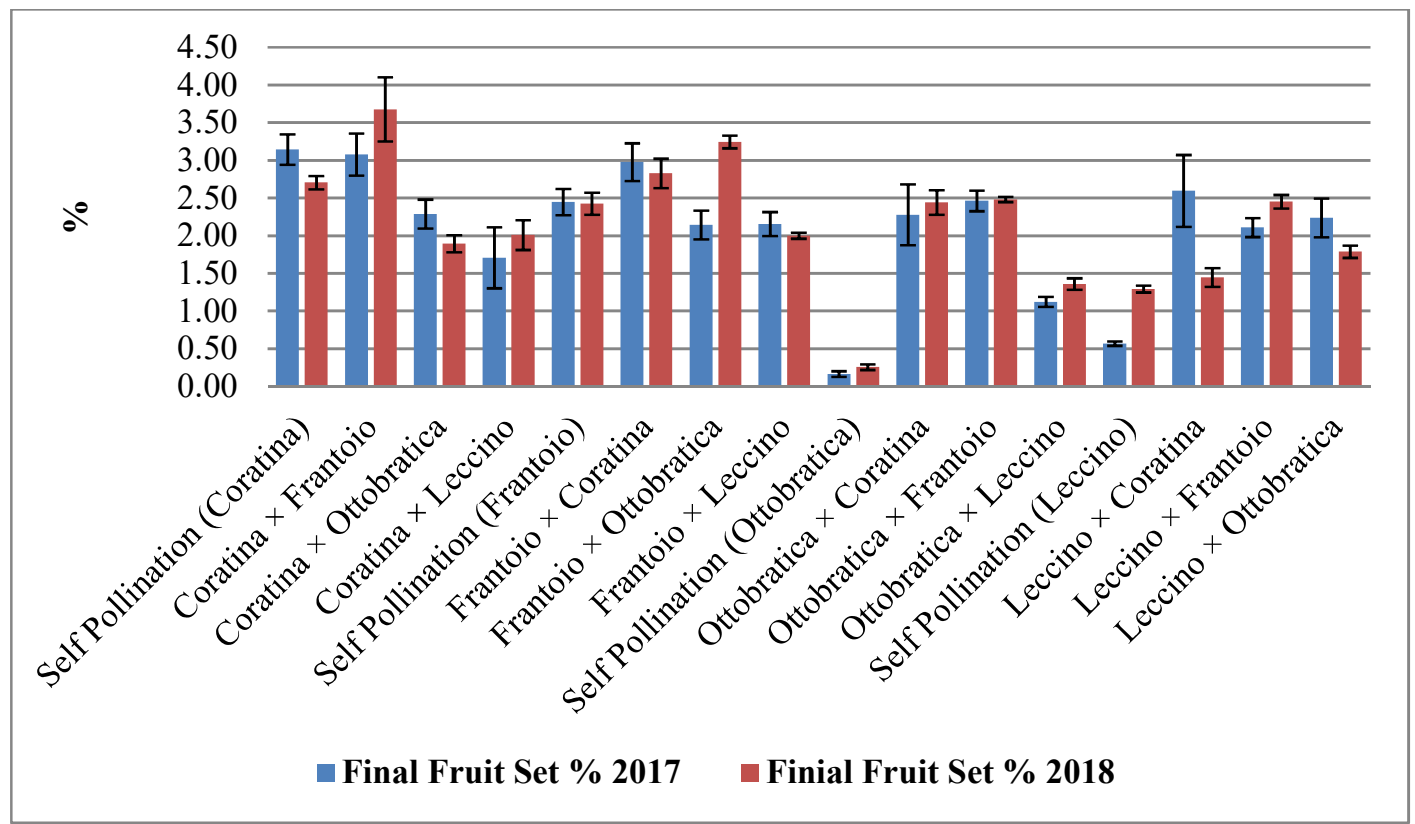

Figure 4. Final fruit set (\%) of four olive varieties during crosses in diallel fashion.

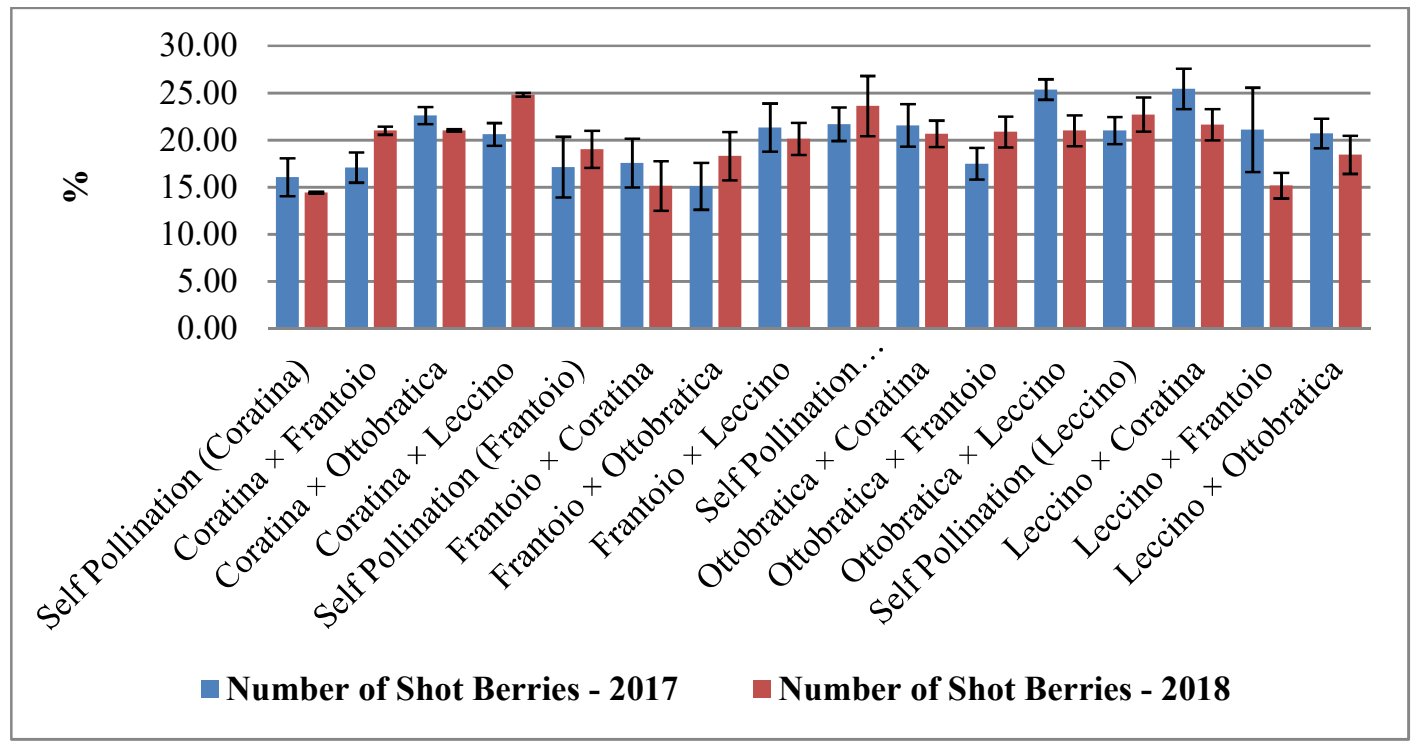

Figure 5. Number of shotberries of four olive varieties during crosses in diallel fashion.

Table 1. Soil physico-chemical status at the location Izhar Olive Farm.

\begin{tabular}{ll}
\hline Type/Quantities & Izhar Olive Farm \\
\hline Texture class & Sandy Loam \\
$\mathrm{pH}$ & 8.1 \\
Organic matter (\%) & 0.55 \\
Nitrogen (\%) & 0.04 \\
Phosphorus (ppm) & 2.6 \\
Potassium (ppm) & 110 \\
Electrical conductivity $\left(\mathrm{dSm}^{-1}\right)$ & 0.55 \\
\hline
\end{tabular}

Table 2. Categories of self-incompatibility according to Zapata and Arroyo (1978).

\begin{tabular}{ll}
\hline $\begin{array}{l}\text { Self-incompatibility } \\
\text { Index }\end{array}$ & State \\
\hline 0 & Completely self-incompatible \\
$<0.2$ & Severely self-incompatible \\
$>0.2<1.0$ & Partially self-incompatible \\
$>1$ & Self-compatible \\
\hline
\end{tabular}


Table 3. Initial fruit set (\%) of four olive varieties during the interaction of self and cross pollination in 2017 and 2018.

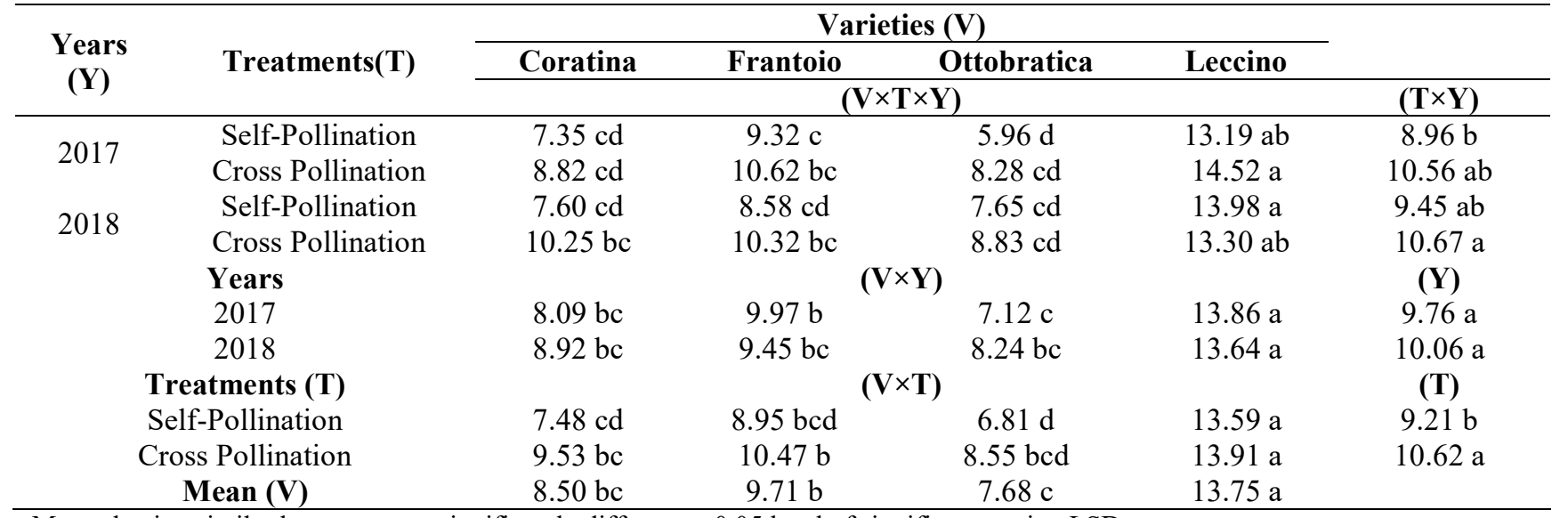

Means having similar letters are not significantly different at 0.05 level of significance using LSD

$\begin{array}{llll}\mathrm{LSD}_{0.05} \text { for } \mathrm{V} & = & 1.62 & \mathrm{LSD}_{0.05} \text { for } \mathrm{V} \times \mathrm{T}= \\ \mathrm{LSD} & 2.29\end{array}$

$\mathrm{LSD}_{0.05}$ for $\mathrm{T} \times \mathrm{Y}=\quad 1.62 \quad \mathrm{LSD}_{0.05}$ for $\mathrm{V} \times \mathrm{T} \times \mathrm{Y}=\quad 3.24$

Table 4. Final fruit set $(\%)$ of four olive varieties during the interaction of self and cross pollination in 2017 and 2018.

\begin{tabular}{|c|c|c|c|c|c|c|}
\hline \multirow{3}{*}{$\begin{array}{c}\text { Years } \\
(\mathbf{Y})\end{array}$} & \multirow{3}{*}{ Treatments(T) } & \multicolumn{4}{|c|}{ Varieties (V) } & \multirow[b]{3}{*}{$(\mathbf{T} \times \mathbf{Y})$} \\
\hline & & Coratina & Frantoio & Ottobratica & Leccino & \\
\hline & & \multicolumn{4}{|c|}{$(\mathbf{V} \times \mathbf{T} \times \mathbf{Y})$} & \\
\hline \multirow{2}{*}{2017} & Self-Pollination & $3.14 \mathrm{~cd}$ & $2.44 \mathrm{e}$ & $0.16 \mathrm{~g}$ & $0.56 \mathrm{~g}$ & $1.58 \mathrm{c}$ \\
\hline & Cross Pollination & $3.98 \mathrm{ab}$ & $3.61 \mathrm{bc}$ & $1.51 \mathrm{f}$ & $1.61 \mathrm{f}$ & $2.68 \mathrm{~b}$ \\
\hline \multirow{2}{*}{2018} & Self-Pollination & $2.70 \mathrm{de}$ & $2.42 \mathrm{e}$ & $0.25 \mathrm{~g}$ & $1.29 \mathrm{f}$ & $1.66 \mathrm{c}$ \\
\hline & Cross Pollination & $3.59 \mathrm{bc}$ & $4.37 \mathrm{a}$ & $2.37 \mathrm{e}$ & $2.37 \mathrm{e}$ & $3.17 \mathrm{a}$ \\
\hline & Years & \multicolumn{3}{|c|}{$(\mathbf{V} \times \mathbf{Y})$} & & $(\mathbf{Y})$ \\
\hline & 2017 & $3.56 \mathrm{a}$ & $3.02 \mathrm{~b}$ & $0.83 \mathrm{e}$ & $1.09 \mathrm{de}$ & $2.13 \mathrm{~b}$ \\
\hline & 2018 & $3.14 \mathrm{~b}$ & $3.39 \mathrm{ab}$ & $1.31 \mathrm{~d}$ & $1.83 \mathrm{c}$ & $2.42 \mathrm{a}$ \\
\hline & Treatments & \multicolumn{3}{|c|}{$(\mathrm{V} \times \mathrm{T})$} & & (T) \\
\hline & Self-Pollination & $2.92 \mathrm{~b}$ & $2.43 \mathrm{c}$ & $0.20 \mathrm{f}$ & $0.92 \mathrm{e}$ & $1.62 \mathrm{~b}$ \\
\hline & Cross Pollination & $3.78 \mathrm{a}$ & $3.99 \mathrm{a}$ & $1.94 \mathrm{~d}$ & $1.99 \mathrm{~d}$ & $2.92 \mathrm{a}$ \\
\hline & Mean (V) & $3.35 \mathrm{a}$ & $3.21 \mathrm{a}$ & $1.07 \mathrm{c}$ & $1.46 \mathrm{~b}$ & \\
\hline
\end{tabular}

Means having similar letters are not significantly different at 0.05 level of significance using LSD

$\begin{array}{llll}\mathrm{LSD}_{0.05} \text { for } \mathrm{V}= & 0.28 & \mathrm{LSD}_{0.05} \text { for } \mathrm{V} \times \mathrm{T}= & 0.40\end{array}$

$\begin{array}{lll}\mathrm{LSD}_{0.05} \text { for } \mathrm{T} \times \mathrm{Y}= & 0.28 & \mathrm{LSD} 0.05 \text { for } \mathrm{V} \times \mathrm{T} \times \mathrm{Y}=\quad 0.57\end{array}$

Table 5. Number of shotberries of four olive varieties during the interaction of self and cross pollination in 2017 and 2018.

\begin{tabular}{|c|c|c|c|c|c|c|}
\hline \multirow{3}{*}{$\begin{array}{c}\text { Years } \\
(\mathbf{Y})\end{array}$} & \multirow{3}{*}{ Treatments(T) } & \multicolumn{4}{|c|}{ Varieties $(\mathrm{V})$} & \multirow[b]{3}{*}{$(\mathbf{T} \times \mathbf{Y})$} \\
\hline & & Coratina & Frantoio & Ottobratica & Leccino & \\
\hline & & \multicolumn{4}{|c|}{$(V \times T \times Y)$} & \\
\hline \multirow{2}{*}{2017} & Self-Pollination & $14.43 \mathrm{de}$ & 17.13 bcde & $21.70 \mathrm{abc}$ & $21.01 \mathrm{abc}$ & $18.57 \mathrm{a}$ \\
\hline & Cross Pollination & 15.95 cde & $15.35 \mathrm{cde}$ & $21.70 \mathrm{abc}$ & $21.63 \mathrm{abc}$ & $18.65 \mathrm{a}$ \\
\hline \multirow{5}{*}{2018} & Self-Pollination & 16.06 cde & 19.03 abcde & $23.61 \mathrm{a}$ & $22.71 \mathrm{ab}$ & $20.35 \mathrm{a}$ \\
\hline & Cross Pollination & 18.50 abcde & $13.15 \mathrm{e}$ & $19.66 \mathrm{abcd}$ & $23.08 \mathrm{ab}$ & $18.60 \mathrm{a}$ \\
\hline & Years $(Y)$ & \multicolumn{4}{|c|}{$(\mathbf{V} \times \mathbf{Y})$} & $(\mathbf{Y})$ \\
\hline & 2017 & $15.19 \mathrm{c}$ & $16.24 \mathrm{c}$ & $21.70 \mathrm{ab}$ & $21.32 \mathrm{ab}$ & $18.61 \mathrm{a}$ \\
\hline & $\begin{array}{c}2018 \\
\text { Treatments }(\mathbf{T})\end{array}$ & \multicolumn{4}{|c|}{$(\mathbf{V} \times \mathbf{T})$} & $\begin{array}{c}19.47 \mathrm{a} \\
\text { (T) }\end{array}$ \\
\hline
\end{tabular}




\begin{tabular}{cccccc}
\hline Self-Pollination & $15.25 \mathrm{~d}$ & $18.08 \mathrm{bcd}$ & $22.65 \mathrm{a}$ & $21.86 \mathrm{ab}$ & $19.46 \mathrm{a}$ \\
Cross Pollination & $17.22 \mathrm{~cd}$ & $14.25 \mathrm{~d}$ & $20.68 \mathrm{abc}$ & $22.35 \mathrm{ab}$ & $18.69 \mathrm{a}$ \\
Mean (V) & $16.23 \mathrm{~b}$ & $16.16 \mathrm{~b}$ & $21.67 \mathrm{a}$ & $22.11 \mathrm{a}$ &
\end{tabular}

Means having similar letters are not significantly different at 0.05 level of significance using LSD

$\begin{array}{llll}\mathrm{LSD}_{0.05} \text { for } \mathrm{V} & =3.20 & \mathrm{LSD}_{0.05} \text { for } \mathrm{V} \times \mathrm{T}= & 4.53\end{array}$

$\begin{array}{rrr}\mathrm{LSD}_{0.05} \text { for } \mathrm{T} \times \mathrm{Y}= & 3.20 & \mathrm{LSD}_{0.05} \text { for } \mathrm{V} \times \mathrm{T} \times \mathrm{Y}=\quad 6.41\end{array}$

Table 6. Self-incompatibility index of four olive cultivars during 2017 and 2018.

\begin{tabular}{|c|c|c|c|c|c|}
\hline \multirow{3}{*}{ Self-Incompatibility } & \multicolumn{4}{|c|}{ Varieties $(\mathbf{V})$} & \multirow[b]{3}{*}{$(\mathbf{Y})$} \\
\hline & Coratina & Frantoio & Ottobratica & Leccino & \\
\hline & \multicolumn{4}{|c|}{$(\mathbf{V} \times \mathbf{Y})$} & \\
\hline 2017 & $0.84 \mathrm{a}$ & $0.78 \mathrm{a}$ & $0.75 \mathrm{ab}$ & $0.91 \mathrm{a}$ & $0.82 \mathrm{a}$ \\
\hline 2018 & $0.77 \mathrm{ab}$ & $0.55 \mathrm{~b}$ & $0.10 \mathrm{c}$ & $0.55 \mathrm{~b}$ & $0.49 \mathrm{~b}$ \\
\hline Mean (V) & $0.80 \mathrm{a}$ & $0.67 \mathrm{a}$ & $0.43 \mathrm{~b}$ & $0.73 \mathrm{a}$ & \\
\hline
\end{tabular}

\section{DISCUSSION}

The present study was designed to investigate the self-incompatibility, cross-compatibility and compatible pollinizer of four Italian cultivars viz. Coratina, Frantoio, Ottobratica, and Leccino, predominantly grown in the olive orchards established under the agro-climatic conditions of Pothwar region of Pakistan. This region of Pakistan has great potential to cultivate olive trees specially cultivars of Coratina, Gemlik, Moraiolo etc (Iqbal et al., 2019 b). Huge olive orchards have been established in this region since the last decade which is mostly dominated by the Italian olive cultivars. Literature showed that the selfincompatibility or cross-compatibility of any given olive cultivar depends upon the geographical area, genotype, and climatic conditions (Torres et al., 2017). Therefore, to get good economic yield from an olive orchard, the maximum number of olive cultivars should be tested in the prevailing environmental conditions for selfincompatibility and cross-compatibility among different olive genotypes.

The results of the present study depicted that the fruit set in open-pollinated treatment was relatively high as compared to self-pollination treatment. A significant increase in the number of fruits set of varieties Coratina and Ottobratica were observed in open-pollination treatment than self-fertilization treatment. Many olive researchers have identified the cross-compatibility of olive genotypes by measuring the amount of fruit set per inflorescence in self and cross-pollination treatments (Lavee et al., 2002; Selak et al., 2011). Moreover, it was also well-documented that many olive cultivars produced more fruit in open-pollination treatment. For instance, Manzanilla, Frantoio, Coratina, Nabali produced little fruit upon self-fertilization while cross- or openpollination enhances the fruit yield many folds (AlKasasbeh et al., 2005; Taslimpour et al., 2008).

Self-incompatibility (SI) in olive is well-known which indicated that the pollen from a plant is not fully able to fertilize its own egg. SI is a very good indicator to classify the olive cultivars into self-incompatible, partially self-incompatible, and self-compatible. So, to get a better understanding of the self-incompatibility of four olive cultivars, the value of SI for each cultivar was calculated. The results depicted that under given environmental conditions the varieties Coratina and Frantoio had relatively less self-infertile as compared to variety Ottobratica which belonged to the self-infertile line. However, the variety Leccino showed a huge variation in the SI value during both the years. The average SI value depicted that variety Leccino belonged to a "relative self-incompatible" category, the same as variety Ottobratica. Controversial result regarding the SI value of cultivars Frantoio and Leccino has been reported in the literature. For instance, Fabbri et al., (2004) reported cv. Frantoio as self-compatible while some other studies categorized this variety as self-incompatible (Mookerjee et al., 2005; Wu et al., 2002).

Similar findings have been reported for the famous Italian cultivar Leccino which has not only cultivated over a vast area of Italy but also other parts of the world (Selak et al., 2014). Under Croatian conditions, the variety Leccino showed the SI value ranged from 0.1 to 0.3 thus classified as self-incompatible cultivar (Selak et al., 2011). The same observation for variety Leccino were reported from north Italy (Spinardi and Bassi, 2012). In contradiction to this, Bartoloni and Guerriero, (1995) reported that variety Leccino is self-compatible in central Italy. The inconsistency of these cultivars in incompatibility response may be explained on the basis of different climatic conditions. Convincing evidence has been reported in the literature about the effect of environmental conditions on the functionality of pollen grains as well as the acceptability of style (Rapoport et al., 2012; Rondanini et al., 2014). Wind pollination, selfincompatibility, and cross-compatibility of cultivated olives are the potential constraints that can greatly affect the economic yield of olive orchards. These factors must 
be considered when planning to establish an olive orchard in any given environment conditions (Moutier, 2002). The present study sheds light on the pollination efficiency of four olive cultivars crossed with each other in all possible combinations. The results revealed that in the reciprocal cross (Frantoio $\times$ Coratina) when variety Coratina was used as pollen parent the percentage of fruits set decreased significantly as compared to direct cross (Coratina $\times$ Frantoio). Similar results were found between variety Leccino and variety Ottobratica.

Overall, the result of the rest of the cross combinations indicated that all the cultivars can efficiently pollinize other cultivars and set good fruit yield $(>2 \%)$. These results are in agreement with the findings of other authors (Al-Kasasbeh et al., 2005; Martin and Sibbett, 2005; Spinardi and Bassi, 2012). It is estimated that 1 to $2 \%$ fruit set in olive is enough to produce good commercial yield (Fabbri et al., 2004). AlKasasbeh et al., (2005) reported that variety Frantoio and variety Coratina are efficient pollinizers for one another. Moutier, (2002) demonstrated the beneficial effect of cross-pollination in various olive cultivars and suggested that proper pollinizer should be ensured in olive groves to get maximum yield. In addition to this, some studies reported that cross-incompatibility in some pairs of the olive cultivar is reciprocal like Mission and Manzanilla (Martin and Sibbett, 2005), whereas scientists proposed that the cross-incompatibility is not always bidirectional but depends upon many factors especially environmental conditions (Lavee et al., 2002).

In conclusion, the results of the present study clearly demonstrated that varieties Coratina, Frantoio, and Leccino possessed partial self-incompatibility while Ottobratica was self-incompatible in agro-climatic conditions of Pothwar region. Cross-pollination or openpollination in varieties Coratina and Ottobratica can enhance the economic yield. All the cultivars can act as good pollinizers as the fruit set percentage in all the crosses were more than $2 \%$ except for the cross Ottobratica $\times$ Leccino which also produced good fruit set ( $>1 \%$ fruit set percentage). Taken together, it can be concluded that these cultivars can be used to establish olive orchards in the Arid climate of Pakistan.

Acknowledgments: We are thankful to Mr. Yaqoob Tahir Izhar Managing Director, Izhar Group of Companies for providing the site for research activity and all related resources during the study period.

Author's Contribution: M.A. Iqbal, A. Mahmood and I.A. Hafiz conceptualized and designed the study. M. Azam and M. A. Khan carried out the methodology and formal analysis. T. Ahmad and A.A. Awan helped in the review, revision and editing. Write up and grammar improvement was made by M. A. Iqbal while M. I. N. Bhatti carried out the statistical analysis.
All authors approved the final version of the manuscript.

\section{REFERENCES}

Anonymous. 2005. SAS Online Doc, Version 8. Cary, $\mathrm{NC}$, United States, SAS Institute.

Al-Kasasbeh, M. F., A. F. Ateyyeh and M. M. Qrunfleh. (2005). A study on self-and cross-pollination of three olive cultivars in Jordan. Dirasat. Agric. Sci. 32.

Awan, A. A., M. Zubair, A. Iqbal, S. J. Abbas and N. Ali. (2011). Molecular analysis of genetic diversity in olive cultivars. Afric. J. Agric. Res. 6: $4937-$ 4940.

Awan, A. A., and Abdul-Rab. (2014). Influence of agroclimatic conditions on fruit yield and oil content of olive cultivars. Pakistan J. Agri. Sci. 51(3): 627-634.

BARI. (2019). Newsletter April-June. http://barichakwal.punjab.gov.pk/

Bartolini, S. and R. Guerriero. (1995). Self-compatibility in several clones of oil olive cv. Leccino. Adv. Hort. Sci. 71-74.

Concepcion, D., M. Trujillo, I. Martinez-Urdiroz, N. Barranco, D. Rallo, L.P. Marfil and B.S. Gauz. (2014). Olive domestication and diversification in the Mediterranean basin. New Phytologist, 206: 436-447.

Cuevas, J., and V. S. Polito. (2004). The role of staminate flowers in the breeding system of Olea europaea (Oleaceae): an andromonoecious, windpollinated taxon. Ann. of Bot. 93: 547-553.

Estruch, R., E. Ros, J. Salas-Salvadó, M. I. Covas, D. Corella, F. Arós,... and R. M. LamuelaRaventos. (2013). Primary prevention of cardiovascular disease with a Mediterranean diet. New Eng. J. Medi. 368: 1279-1290.

Fabbri, A., G. Bartolini, M. Lambardi and S. Kailis. (2004). Olive propagation manual. Landlinks Press. 18-23.

Iqbal, M. A., I. A. Hafiz, N. A. Abbasi and M. K. N. Shah. (2019). Morphological, phenological characterization and adaptability of exotic olive cultivars in district Chakwal, Pakistan. Pakistan J. Agri. Sci. 56: 587-594.

Iqbal, M. A., I. A. Hafiz, N. A. Abbasi and M. K. N. Shah. $\left(2019^{\mathrm{b}}\right)$. Adaptability, agronomic and yield performance of exotic olive (olea europaea) cultivars in Pothwar region of Pakistan. Pakistan J. Bot. 51: 1745-1751.

Kiran, H. (2017). Pakistan need to be self-sufficient in edible oil production. J. Energ. Technol. Polic. 7: 48-57.

Koubouris, G. C., I. T. Metzidakis and M. D. Vasilakakis. (2009). Impact of temperature on olive (Olea 
europaea L.) pollen performance in relation to relative humidity and genotype. Environ. Exp. Bot. 67: 209-214. Anonymous. 2005. SAS Online Doc, Version 8. Cary, NC, United States, SAS Institute.

Lavee, S., H. Harshemesh, and N. Avidan. (1985). Phenolic acids-possible involvement in regulating growth and alternate fruiting in olive trees. Intern. Symp. Grow. Regul. Fruit Prod. 179: 317-328.

Lavee, S., J. Taryan, J. Levin and A. Haskal. (2002). The significance of cross-pollination for various olive cultivars under irrigated intensive growing conditions. Olivae. 91: 25-36.

Malik, N. S. and J. L. Perez. (2011). The effect of high temperature interruptions during inductive period on the extent of flowering and on metabolic responses in olives (Olea europaea L.). Sci. Hort. 129(2): 207-212.

Mansour, T. G., H.B, Hassan, S.A. El-Ghani, and E.M. Khalil. (2018). The Tunisian experience in olive production and marketing and how to benefit from it in the Egyptian case. Middle East J. 7(3): 1154-1164.

Martin, G. C. and G.S. Sibbett. (2005). Botany of the olive. Olive production manual, $2^{\text {nd }}$ edition. Uni. of Cali. 35-49.

Mookerjee, S., J. Guerin, G. C. Ford and M. Sedgley. (2005). Paternity analysis using microsatellite markers to identify pollen donors in an olive grove. Theoret. Appl. Genet. 111: 1174-1182.

Moutier, N. (2002). Self-fertility and inter-compatibilities of sixteen olive varieties. Acta. Hort. 586: 209212.

PARC. (2018). http://parc.gov.pk/index.php/en/oliveachievements

Rapoport, H. F. (2012). The reproductive biology of the olive tree and its relationship to extreme environmental conditions. VII Int. Symp. Olive Grow. 1057: 41-50.

Rashid A. J. (2018). Third Pakistan edible oil conference, Karachi. http://www.peoc.com.pk

Rondanini, D. P., D. N. Castro, P. S. Searles and M. C. Rousseaux. (2014). Contrasting patterns of fatty acid composition and oil accumulation during fruit growth in several olive varieties and locations in a non-Mediterranean region. Eur. J. Agron. 52: 237-246.

Saumitou-Laprade, P., P. Vernet, X. Vekemans, S. Billiard, S. Gallina, L. Essalouh, A. Mhaïs, A. Moukhli, A. El Bakkali and G. Barcaccia. (2017). Elucidation of the genetic architecture of self-incompatibility in olive: Evolutionary consequences and perspectives for orchard management. Evol. App. 10: 867-880.

Selak, G.V., J. Cuevas, S.G. Ban and S. Perica. (2014). Pollen tube performance in assessment of compatibility in olive (Olea europaea L.) cultivars. Scie. Horti. 165: 36-43.

Selak, G.V., S. Perica, S.G. Ban, M. Radunic and M. Poljak. (2011). Reproductive success after selfpollination and cross-pollination of olive cultivars in Croatia. Hort. Sci. 46: 186-191.

Spinardi, A. and D. Bassi. (2012). Olive fertility as affected by cross-pollination and boron. The Scien. Wor. J. 12-20.

Taslimpour, M. R., A. R. Bonyanpour and M. Rahemi. (2008). Determining the best pollenizer of olive (Olea europaea L.) in Fars Province. Amer.-Eur. J. Agri. Environ. Sci. 4: 682-686.

Torres, M., P. Pierantozzi, P. Searles, M.C. Rousseaux, G. García-Inza, A. Miserere, R. Bodoira, C. Contreras and D. Maestri. (2017). Olive cultivation in the southern hemisphere: flowering, water requirements and oil quality responses to new crop environments. Front. in Plant Sci. 8: 1830.

Webster, A.D. (2002). Factors influencing the flowering, fruit set and fruit growth of European pears. Acta Hort. 596: 699-709.

Wu, S.B., G. Collins and M. Sedgley. (2002). Sexual compatibility within and between olive cultivars. J. Horti. Sci. Biotech. 77: 665-673.

Zapata, T.R. and M.T.K. Arroyo. (1978). Plant reproductive ecology of a secondary deciduous tropical forest in Venezuela. Biotrop. 221-230. 